\title{
Effects of gastrointestinal hormones on the growth of human intestinal epithelial cells in vitro
}

\author{
C SIMOPOUlOS*, J D GAFFEN, AND A BENNETT \\ From the Department of Surgery, King's College School of Medicine and Dentistry, London
}

\begin{abstract}
SUMMARY The growth of cultured epithelium like cells from human normal embryonic intestine was studied in response to various hormones using a method that quantifies the number of cells by the amount of dye that they bind after fixation. Gastrin and neurotensin in the $\mathrm{pg} / \mathrm{ml}$ range and higher caused small increases in cell growth. Glucagon and VIP were stimulatory in the low ng/ml range, whereas somatostatin and bombesin had no effect at the lower concentrations but were stimulatory at the highest concentration tested $(10$ and $100 \mathrm{ng} / \mathrm{ml}$ respectively). Secretin and pancreozymin (cholecystokinin) seemed to be ineffective.
\end{abstract}

Gastrointestinal hormones regulate the metabolism and growth of most gastrointestinal tissues.' In patients with the Zollinger-Ellison syndrome mucosal hyperplasia and hypergastrinaemia occur, ${ }^{2.3}$ whereas in antrectomised patients the oxyntic gland mucosa usually atrophies. ${ }^{4}$ These clinical observations provided initial evidence of a trophic role for gastrin. With gastrointestinal mucosae in vitro and in vivo gastrin and pentagastrin stimulate cell growth and the synthesis of protein, RNA, and DNA; pentagastrin increased the growth of human normal gastric mucosal cells and colonic malignant cells in vitro, ${ }^{7}$ and gastrin increased the proliferation and the rate of $\left[{ }^{3} \mathrm{H}\right]$-thymidine incorporation into the DNA of the IEC- 6 crypt cell line from rat small intestine. ${ }^{*}$

There is comparatively little work on the roles of various other gut hormones as growth regulators of gastrointestinal mucosae in vivo or in vitro..$^{y-12} \mathrm{~A}$ trophic effect of CCK on the digestive mucosa is disputed..$^{12-15}$ Secretin in vivo is reported to have an antitrophic effect on rat jejunal and ileal mucosae, ${ }^{16} 17$ and it reduced the DNA and protein content in organ cultured rabbit ileum. ${ }^{12}$ Secretin, however, had little or no effect on rabbit jejunum, ${ }^{12}$ and it caused duodenal hyperplasia in the rat. ${ }^{18}$. Glucagon enhanced the growth of cultured human colorectal

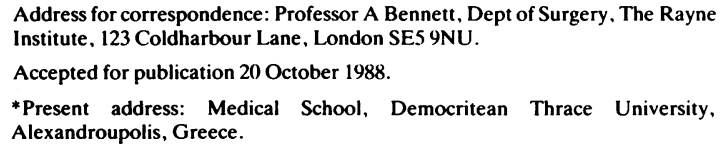

cancer cells. ${ }^{19}$ Somatostatin $2-20 \mathrm{ng} / \mathrm{ml}$ increased the growth of human gastric cancer cells, but inhibited the growth of normal epithelial cells from human gastric mucosa at $20-100 \mathrm{ng} / \mathrm{ml}^{10}$ and had little or no effect on rat intestinal IEC-6 cells. ${ }^{8}$ Vasoactive intestinal peptide (VIP) and neurotensin do not appear to have been previously studied on any aspect of proliferation, and we have not found any reports on the effects of secretin, pancreozymin, or bombesin on the growth of isolated gut epithelial cells.

We now report studies of eight naturally occurring peptides on the growth in culture of epithelium like cells from human normal embryonic intestine. The peptides are gastrin (G-17), glucagon, pancreozymin, and secretin (which occur mainly in the gut), and somatostatin, neurotensin, bombesin, and VIP (which occur also in the central nervous system).

\section{Methods}

\section{CELLS AND THEIR CULTURE}

Epithelial-like cells from human normal embryonic intestine (Flow Laboratories, no 407) were grown as monolayers in Eagle's basal medium (BME) supplemented with $15 \%$ newborn bovine serum (NBS) and $50 \mathrm{IU} / \mathrm{ml}$ each of penicillin and streptomycin, in a humidified atmosphere of air/ $/ \mathrm{CO}_{2}(95: 5)$ at $37^{\circ} \mathrm{C}$. The medium was prepared from powder (Flow Laboratories), using water that was double distilled in glass; sterilisation was by filtration. 


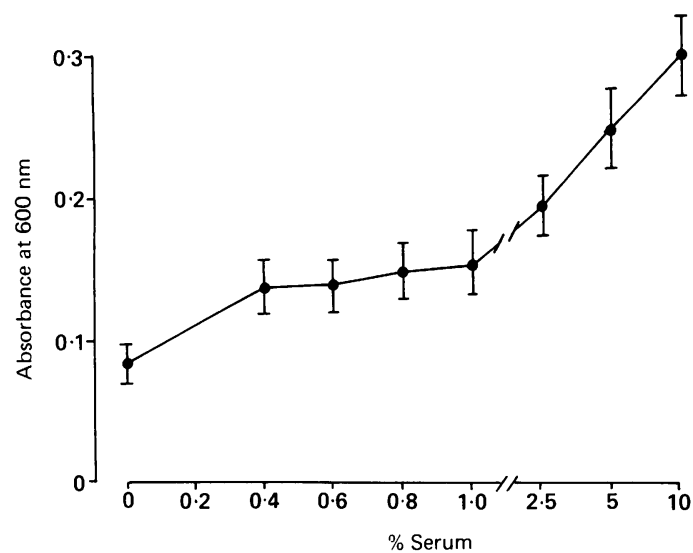

Fig. 1 Serum concentration effect curve for the growth of epithelium-like cells from human normal embryonic intestine, as measured spectrophotometrically by the amount of dye eluted. Results are expressed as the mean (SE) of the separate means from four experiments each with 16-24 replicates.

These cells grow rapidly in medium containing high concentrations of serum. In order to ensure that we could detect either stimulation or inhibition of growth by the peptides, we determined a lower serum concentration which gave moderate cell growth. From the curve (Fig. 1), constructed using $0-10 \%$ NBS by the method described below, 1\% NBS seemed optimal.

Cell growth was assessed by a dye method. ${ }^{20}$ The cells were detached by treatment with trypsin/EDTA $(0 \cdot 5 \%: 0.02 \% \mathrm{w} / \mathrm{v})$ to produce a single cell suspension, counted (Coulter counter, model DN), and diluted in $\mathrm{BME}+15 \% \mathrm{NBS}$ so that $100 \mu \mathrm{l}$ contained 6000 cells. Aliquots of $100 \mu \mathrm{l}$ were added to each well of a 96-well microtest plate, except for one row of four which were used as medium blanks. The final volume in each well was made up to $200 \mu \mathrm{l}$, and the cells were left to adhere to the microtest plates (five hours in air $/ \mathrm{CO}_{2} 95: 5,37^{\circ} \mathrm{C}$ ). After removing the lid, each plate was inverted and the medium expelled by three firm downward shakes. The cells were then washed with $100 \mu \mathrm{l}$ serum free medium. Each peptide or its vehicle was added in $200 \mu \mathrm{l}$ BME containing $1 \%$ NBS. Two peptides and the vehicle(s) were studied simultaneously at all concentrations on the same plate. After three days' incubation, the medium was removed and the cells were fixed for 15 minutes by adding $100 \mu \mathrm{l} 10 \%$ formol saline to each well. After 15 minutes the fixative was replaced with stain $(12.2 \mathrm{mM}$ crystal violet in $154 \mathrm{mM} \mathrm{NaCl}$, filtered) which was then removed 15 minutes later. The wells were rinsed twice with distilled water, dried in air for five to six hours, and the stain in the cells was

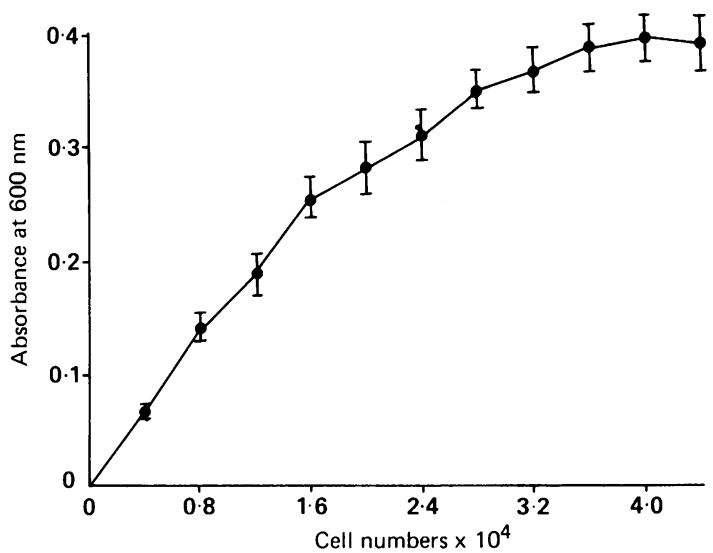

Fig. 2 Cell numbers showed a curvilinear relationship to the amount of dye eluted, as measured by spectrophotometry. Results are expressed as the mean ( $S E$ ) of the separate means from five experiments each with eight replicates. All of our cell growth studies with hormones gave readings on the linear part of the curve.

eluted with $100 \mu \mathrm{l}$ acidified methanol (five drops $1 \mathrm{M}$ $\mathrm{HCl}$ to $100 \mathrm{ml}$ methanol). Light absorption through each well was read at $600 \mathrm{~nm}$ using a Dynatech microplate reader. Although the cells remained in each well, the absorption was almost entirely the result of the dye; the cells accounted for $0.5-1 \%$ of the readings, as shown by measurements before and after eluting the dye from them. Calibration curves were constructed to determine the relationship between cell numbers and dye concentration, using 4000 to 44000 cells/well in increments of 4000 (eight wells/increment). When the cells had attached to the plate (at five hours) the medium was removed and the cells were fixed and stained as described above. Five separate experiments were done with each peptide (plus additional ones for gastrin, see later) giving a total of 40 replicates at each point. The results are expressed as the mean of the separate means (SE) from each experiment. Cell numbers showed a curvilinear relationship to the amount of dye eluted, as measured by spectrophotometry (Fig. 2).

Glucagon was dissolved in water adjusted to $\mathrm{pH}$ 8.8 using $0.1 \mathrm{M} \mathrm{NaOH}$, and diluted in the same solvent. The other peptides were dissolved and diluted in sterile $154 \mathrm{mM} \mathrm{NaCl}$. All the water was double distilled in glass, and sterilisation was by filtration. Log concentration effect curves were constructed for the eight gastrointestinal peptides, gastrin G-17, glucagon, pancreozymin (CCK), secretin, somatostatin, neurotensin, bombesin, and VIP (all from Sigma). They were used in five concentrations in the following 10-fold ranges: gastrin 2 to $20000 \mathrm{pg} / \mathrm{ml}$; pancreozymin $0 \cdot 02-200$ 
$\mu$ Crick units; glucagon, somatostatin, neurotensin, and VIP 1 to $10000 \mathrm{pg} / \mathrm{ml}$; secretin 0.01 to 100 $\mu$ Crick units $/ \mathrm{ml}$; bombesin 10 to $100(000) \mathrm{pg} / \mathrm{ml}$.

In other experiments with gastrin, the cell diameters were measured using an eyepiece graticule calibrated with a microscope stage micrometer.

STATISTICAL ANAIYYSIS

In each experiment the mean reading in eight wells (12 for controls except in the cell size experiments) was calculated. The mean (SE) of the means was analysed by Student's $t$ test for paired data (twotailed) to determine the difference from vehicle controls.

\section{Results}

EFFECT OF GASTRIN ON CELL SIZE

The results for growth, expressed in absorbance units, are the mean of the four means from each experiment, with 40 replicates/experiment for controls, and eight replicates/experiment for gastrin. Cell diameter $(\mu \mathrm{m})$ is the mean of the means from 100 replicates/experiment for controls and 20 replicates/experiment for gastrin. The amount of dye bound to the fixed cells presumably depends on number and size. With gastrin, measurements of the amount of dye eluted from the cells probably represent cell numbers, because gastrin 20 and $200 \mathrm{pg} / \mathrm{ml}$ increased the amount of dye by $6(2) \%$ and $10(3) \%$ respectively $(p<0.05)$ but had little or no effect on cell size; the differences in mean cell diameters were $-2 \cdot 2 \%$ and $1 \cdot 2 \%$ respectively $(p>0 \cdot 4)$.

\section{EFFECT ON CELLGROWTH, AS IMPLIED BY DYE BINDING}

The effects of gastrin (G-17), neurotensin, glucagon, VIP, somatostatin, bombesin, secretin, and pancreozymin (CCK) on the growth of human intestinal epithelial cells (expressed as light absorbance at 600 $\mathrm{nm} \times 100$ ) are shown in the Table. Each point is the mean (SE) of the separate means from six experiments each with eight replicates (eight wells) for peptides and 12 replicates for controls. The results with gastrin are separate from those above concerned with cell size.

Gastrin and neurotensin, in the $\mathrm{pg} / \mathrm{ml}$ range and higher, caused small increases in cell growth, as indicated by the greater amount of dye (Table). Glucagon and VIP were stimulatory in the low $\mathrm{ng} / \mathrm{ml}$ range, whereas somatostatin and bombesin had no effect at the lower concentrations but were stimulatory at the highest concentration tested (10 and 100 $\mathrm{ng} / \mathrm{ml}$ respectively). Secretin and pancreozymin seemed to be ineffective at all concentrations tested (Table).
Table 1 Effect of various peptides on the growth of epithelium-like cells from human normal embryonic intestine

\begin{tabular}{|c|c|c|c|c|c|c|}
\hline Peptide & 1 & 10 & $10(x)$ & $10(x)$ & $10(x)(0)$ & $10(0000)$ \\
\hline Gastrin* & $12(7)$ & $19(9)$ & $18(10)$ & $21(9)$ & $18(10)$ & \\
\hline $\mathrm{P}$ & $<0 \cdot(0) 2$ & $<0 \cdot(0)$ & $<0) \cdot(02$ & $<0 \cdot() 1$ & $<0.05$ & \\
\hline Neurotensin & $6(7)$ & $8(7)$ & $10(7)$ & $10(8)$ & $15(7)$ & \\
\hline $\mathrm{P}$ & 0.1 & 0.025 & $<0.05$ & $<0.05$ & $<0 \cdot(1) 2$ & \\
\hline Glucagon & $3(9)$ & $3(9)$ & $4(7)$ & $8(6)$ & $20(10)$ & \\
\hline $\mathrm{P}$ & $<0 \cdot 4$ & $<0 \cdot 4$ & $<0 \cdot 2$ & $<0.05$ & $<() \cdot 01$ & \\
\hline VIP & $1(8)$ & $4(8)$ & $4(7)$ & $15(10)$ & $23(9)$ & \\
\hline$P$ & $<0.9$ & $<0.3$ & $<() \cdot 4$ & $<0.02$ & $<0 .(0) 5$ & \\
\hline Somatostatin & $-3(7)$ & $-1(9)$ & $9(10)$ & $10(9)$ & $26(10)$ & \\
\hline $\mathrm{P}$ & $<0.7$ & $<0.9$ & $<() \cdot 3$ & $<0 \cdot 3$ & $<0 .(15)$ & \\
\hline Bombesin & & $4(4)$ & $3(5)$ & $3(6)$ & $8(8)$ & $11(8)$ \\
\hline $\mathrm{P}$ & & $<0 \cdot 4$ & $<0 \cdot 3$ & $<0.3$ & $<0 \cdot 1$ & $<0.05$ \\
\hline & $0 .(01$ & $(0 \cdot 1$ & 1 & 10 & $10(x)$ & $\mu \mathrm{CU} / \mathrm{ml}$ \\
\hline Secretin & $6(10)$ & $-7(6)$ & $-6(8)$ & $0(7)$ & $15(8)$ & \\
\hline $\mathbf{P}$ & $<0.9$ & $<0 \cdot 1$ & $<0 \cdot 2$ & $<1 \cdot 0$ & $<0 \cdot 2$ & \\
\hline Pancreozymin* & $11(13)$ & $2(6)$ & $2(6)$ & $6(6)$ & $7(4)$ & \\
\hline $\mathrm{P}$ & $<0 \cdot 2$ & $<0.5$ & $<0 \cdot 3$ & $<0.2$ & $<0 \cdot 2$ & \\
\hline
\end{tabular}

*Double the concentration shown - that is, $2-20000 \mathrm{pg} / \mathrm{ml}$ for gastrin and $(0 \cdot(2)-2(0) \mu \mathrm{CU} / \mathrm{ml}$ for pancreozymin). The results are $\%$ change in the amount of dye eluted, compared with vehicle controls. Increased cell growth occurred with gastrin $(2-20(0) 0 \mathrm{pg} / \mathrm{ml})$. neurotensin $(10-10000 \mathrm{ng} / \mathrm{ml})$, glucagon $(1 \mathrm{ng} / \mathrm{ml})$. VIP $(10 \mathrm{ng} / \mathrm{ml})$, somatostatin $(10 \mathrm{ng} / \mathrm{ml})$, and bombesin $100 \mathrm{ng} / \mathrm{ml}$. Secretin and pancreozymin appeared to have no effect. $P$ represents the probability of the difference compared with vehicle controls.

\section{Discussion}

As stated in the introduction, many studies in vivo and in vitro indicate that gastrin has a trophic effect on gastrointestinal tissues. Apart from clinical observations, ${ }^{2-}$ most work has been in laboratory animals. Our studies show that gastrin has a trophic effect on cells from human embryonic intestinal epithelium. Although, we cannot exclude the possibility that gastrin or the other hormones altered the cell surface proteins or binding of dye by the cells, the effect of fixing by formaldehyde before adding the dye presumably far outweighs any small peptide mediated changes that might occur.

Glucagon also stimulated epithelial cell replication in our experiments, consistent with the finding that the hormone enhanced the growth of human colon cancer cells in culture. ${ }^{19}$ High doses of glucagon in suckling rats, however, did not induce the early adaptation of the small bowel mucosa which occurs at weaning," athough in a patient with an endocrine tumour that secreted enteroglucagon (which is closely related to glucagon) the intestinal mucosa was hypertrophied;:-2 extracts of the tumour injected into mice also appeared to cause hypertrophy of the intestinal mucosa. Other extracts rich in enteroglucagon may directly stimulate crypt cell production..$^{2324}$ 
Somatostatin stimulated intestinal cell growth at the highest concentration $(10 \mathrm{ng} / \mathrm{ml})$, but lower concentrations were ineffective. The growth of normal human gastric mucosal cells was enhanced by $1 \mathrm{ng} / \mathrm{ml}$ somatostatin, whereas inhibition occurred with $20-100 \mathrm{ng} / \mathrm{ml} .^{10}$ With rabbit cultured intestinal mucosa somatostatin reduced the DNA and protein content of the jejunum but not the ileum. " There was little or no effect of somatostatin 10-500 ng/ml on the numbers of rat IEC- 6 cells or their incorporation of $\left[{ }^{3} \mathrm{H}\right]$-thymidine into DNA. ${ }^{8}$

We found that bombesin stimulated the growth of human intestinal cells at the highest concentration tested. This peptide also stimulated the growth of the gastrointestinal tract and pancreas in suckling rats, ${ }^{25}$ causing both hypertrophy and hyperplasia depending on the dose and the duration of the treatment.

Secretin was ineffective in our studies. In rats, secretin alone or with pentagastrin had little or no effect on the parietal cell mass, ${ }^{26}$ but it inhibited gastrin stimulated DNA synthesis and accumulation in the gastric oxyntic region and duodenum. ${ }^{17}$

We obtained no effect of pancreozymin (CCK) on cell growth, consistent with the finding that CCK $0 \cdot 1$ $\mathrm{nM}-1 \mu \mathrm{M}$ did not influence the DNA or protein content of rabbit small intestine in organ culture..$^{13}$ In rats, however, acute and chronic administration of the CCK-related peptide caerulein induced duodenal hyperplasia, but caused only transient hypertrophy of the oxyntic gland area, ${ }^{18}$ and in another study chronic administration of caerulein to rats stimulated epithelial cell proliferation in the gastric antral mucosa. ${ }^{14}$

Our results with neurotensin and VIP appear to be the first concerning effects on cell growth. These findings, and those with the other peptides, represent the first direct evidence that some of them have a trophic action on epithelial cells from human embryonic intestine in vitro. The findings may be physiologically relevant, as the peptide concentrations were appropriately low, ${ }^{27}$ and the results generally agree with in vivo studies.

The findings, however, must be treated with caution. As with all cell culture studies, it is not known to what extent cell changes during culture affect the responses, or how much resemblance there is to effects in vivo. The artificial conditions during culture unavoidably lead to great differences from those in vivo. We used newborn bovine serum which itself affects cell growth, and in vivo there may be simultaneous exposure to many hormones present in the bloodstream or reaching the cells by other means.

The 10000 -fold range of concentrations that we used almost inevitably means that the higher amounts are physiologically excessive compared with normal blood concentrations. High concentrations may occur in disease, however, and surges in the plasma concentrations of several gastrointestinal hormones, including enteroglucagon, gastrin, neurotensin, and pancreozymin occur after in full term ${ }^{2 *}$ or preterm ${ }^{29}$ enterally fed infants, but not in those deprived of enteral feeding." These hormones may therefore have a role in the structural and functional changes that accompany postnatal adaptation to human extra-uterine nutrition. ${ }^{3132}$ Our results showing that some of these hormones have a trophic effect on human embryonic intestinal cells in vitro support this hypothesis.

\section{References}

1 Johnson LR. Regulation of gastrointestinal growth. In: Johnson LR, ed. Physiology of the gastrointestinal tract. New York: Raven Press, 1987: vol 301-33.

2 Gregory A, Grossman MI, Tracy HJ, Bently PH. Nature of the gastric secretogogue in Zollinger-Ellison tumours. Lancet 1967; ii: 543-4.

3 Ellison EH, Wilson SD. Further observation on factors influencing the symptomatology manifest by patients with Zollinger-Ellison syndrome. In: Shnitka TK. Gilbert JAL, Harrison RC, eds. Gastric secretion. New York: Pergamon, 1967: 363-9.

4 Lees F. Grandjean LC. The gastric and jejunal mucosa in healthy patients with partial gastrectomy. Arch Intern Med 1968; 101: 9437-51.

5 Johnson LR, Guthric PD. Stimulation of DNA synthesis by big and little gastrin (G-34 and G-17). Gastroenterology 1976: 71: 599-602.

6 Enochs MR. Johnson LR. Changes in protein and nucleic acid synthesis in rat gastric mucosa after pentagastrin. Am J Physiol 1977; 232: 223-8.

7 Sirinek KR, Levine BA. Moyer MP. Pentagastrin stimulates in vitro growth of normal and malignant human colon epithelial cells. Am J Surg 1985; 149: 35-9.

8 Conteas CN. Nandi Majumdar AP. The effects of gastrin, epidermal growth factor, and somatostatin on DNA synthesis in a small intestinal crypt cell line (IEC-6). Proc Soc Exp Biol Med 1987; 184: 307-11.

9 Johnson LR. Effect of exogenous gut hormones on gastrointestinal mucosal growth. Scand J Gastroenterol 1982; 74: 89-92.

10 Moyer AP. Armstrong A, Aust JB, Levine BA, Sirinck KR. Effects of gastrin, glutamine and somatostatin on the in vitro growth of normal and malignant human gastric mucosal cells. Arch Surg 1986; 121: 28.5-8.

11 Stange EF, Schncider A. Schusdziarra V. Ditshuncit H. Inhibitory effects of somatostatin on growth and differentiation in cultured intestinal mucosa. Horm Metab Res 1984; 16: 74-8.

12 Stange EF, Schneider A, Seiffer E, Ditshuncit H. Effect of pentagastrin, secretin and cholecystokinin on growth and differentiation in organ cultured rabbit small intestine. Horm Metab Res 1986; 18: 303-7.

13 Johnson LR, Guthric PD. Effect of CCK and 16,16dimethyl $\mathrm{PGE}_{2}$ on RNA and DNA of gastric and duodenal mucosa. Gastroenterology 1976; 70: 59-65.

14 Caes F, Willems G. The effect of gastrin and CCK-like 
peptides on epithelial cell proliferation in the stomach. Scand J Gastroenterol 1984; 19 [suppl 101]: 7-11.

15 Gornacz GE, Ghatei MA, Ali-Mukhtar MYT, et al. Plasma enteroglucagon and CCK levels and cell proliferation in defunctioned small bowel in the rat. Dig Dis Sci 1984; 29: 1041-9.

16 Pansu D, Berard A, Bechelette NA, Labert R. Influence of secretin and pentagastrin on the circadian rhythm of cell proliferation in the intestinal mucosa in rats. Digestion 1974; 11: 266-74.

17 Johnson CR, Guthric PD. Secretin inhibition of gastrin stimulated deoxyribonucleic acid synthesis. Gastroenterology 1974; 67: 601-6.

18 Morisset J, Genik P. Effects of acute and chronic administration of secretin and cacrulein on rat duodenal and gastric growth. Regul Pept 1983; 5: 111-23.

19 Moyer MP, Aust JB, Dixon PS, Levine BA, Sirinek KR. Glucagon enhances growth of cultured human colon cancer cells. Am J Surg 1985; 150: 676-9.

20 Barer MJ, Lyon H, Drasar BS. Quantitation of dye binding by cell monolayers in a microtiter system. Histochem J 1986; 18: 122-8.

21 Buts JP, DeMeyer R, Van Craynest MP, Maldague P. Pancreatic glucagon does not alter mucosal growth and maturation of sucrase and thymidine kinase activity in rat small intestine. Biol Neonate 1983; 43: 253-62.

22 Bloom SR, Polak JM. The hormonal pattern of intestinal adaptation. A major role for enteroglucagon. Scand J Gastroenterol 1982; 72: 409-20.

23 Holst JJ. Gut glucagon, enteroglucagon, gut glucagonlike immunoreactivity, glicentin-current status. Gastro- enterology 1983; 84: 1602-13.

24 Uttenthal LO, Batt RM, Carter MW, Bloom SR. Stimulation of DNA synthesis in cultured small intestine by partially purified enteroglucagon. Regul Pept 1982; 3: 84.

25 Lehy T, Puccio F, Chariot J, Labeille D. Stimulating effect of bombesin on the growth of gastrointestinal tract and pancreas in suckling rats. Gastroenterology 1986; 90: 1942-9.

26 Stanley MD, Coalson RE, Grossman MI, Johnson LR. Influence of secretin and pentagastrin on acid secretion and parietal cell number in rats. Gastroenterology 1972; 63: $264-7$.

27 Eastham RD. Biochemical values in clinical medicine. Bristol: Wright, 1985.

28 Lucas A, Adrian TE, Christofides ND, Bloom SR. Aynsley-Green A. Plasma motilin, gastrin and enteroglucagon and feeding in the human newborn. Arch Dis Child 1980; 55: 673-7.

29 Lucas A, Bloom SR, Aynsley-Green A. Postnatal surges in plasma gut hormones in term and pre-term infants. Biol Neonate 1982; 41: 63-7.

30 Lucas A, Bloom SR, Aynsley-Green A. Metabolic and endocrine consequences of depriving pre-term infants of enteral nutrition. Acta Paediatr Scand 1983; 72: 245-9.

31 Lucas A, Bloom SR, Aynsley-Green A. Gut hormones and 'minimal enteral feeding'. Acta Paediatr Scand 1986; 75: 719-23.

32 Aynsley-Green A. The role of regulatory peptides in postnatal metabolic adaptation. Acta Endocrinol 1986; 113 [Suppl 279]: 422-7. 